\title{
Dynamics of green and blue water flows and their controlling factors in Heihe River basin of northwestern China
}

\section{Kaisheng Luo ${ }^{1,2}$, Fulu Tao ${ }^{*}$}

${ }^{1}$ Key Laboratory of Land Surface Pattern and Simulation, Institute of Geographical Sciences and Natural Resources

${ }^{2}$ University of Chinese Academy of Sciences, Beijing, 100101, China

*Corresponding Author: Fulu Tao (taofl@igsnrr.ac.cn)

Abstract. Climate variation will affect hydrological cycle, as well as the availability of water resources. In spite of large progresses have been made in the dynamics of hydrological cycle variables, the dynamics and drivers of blue water flow, green water flow and total flow (three flows), as well as the proportion of green water (GWC), in the past and future at county scale, were scarcely investigated. In this study, taking the Heihe River basin in China as an example, we investigated the dynamics of green and blue water flows and their controlling factors during 1980-2009 using five statistical approaches and the Soil and Water Assessment Tool (SWAT). We found that there were large variations in the dynamics of green and blue water flows during 1980-2009 at the county scale. Three flows in all counties showed an increasing trend except Jiayuguan and Jianta county. The GWC showed a downward trend in the Qilian, Suzhou, Shandan, Linze and Gaotai counties, but an upward trend in the Mingle, Sunan, Jinta, Jiayuguan, Ganzhou and Ejilaqi counties. In all the counties, the three flows and GWC had strong persistent trends in the future, which are mainly ascribed to rainfall variation. In the Qilian and Shandan counties, rainfall was the major controlling factor for the three flows and GWC. Rainfall controlled the green water and total flows in the Mingle, Linze and Gaotai counties; green water flow and GWC in the Suzhou county; green water flow, total flow and GWC in the Jinta and Ejilaqi counties. Our results also showed that the "Heihe River basin allocation project" had significant influences on the abrupt changes of the flows above-mentioned. Our results illustrate the status of the water resources at county scale, providing a reference for water resources management of inland river b asins.

\section{Introduction}

Much attention has been paid to the influence of climate variation on water resource all over the world (Jeuland and intensify (Qiao et al., 2014; Zuo et al., 2015), studies have shown global climate change has led to reduction of water resource (Kundzewicz et al., 2008; Ravazzani et al., 2014), and exacerbated the shortage of water in the semi-arid regions. Water scarcity can endanger the food safety and sustainable development of economy, as well as the health of the ecosystem (Cheng et al., 2007; Piao et al., 2010). 
(Falken mark and Rockstrom, 2006; Faramarzi et al., 2009; Li et al., 2010; Schuol et al., 2008). In the view of stock, green water is reserved in soil from precipitation, and blue water comprises the water in the rivers, lakes, wetlands and shallow aquifers. From the perspective of flux, green water refers to actual evapotranspiration, and blue water includes the liquid water flows. Many scholars have undertaken related studies since the appearance of this notion (Faramarzi et al., 2009; Jewitt et al., 2004; Liu et al., 2009b; Rost et al., 2008; Sulser et al., 2010; Xu and Zuo, 2014). Current reaches in the quantitatively assessing (Chen et al., 2015; Chukalla et al., 2015; Schuol et al., 2008) and theory frame develop, as well as related model designs (Faramarzi et al., 2009). But overall, previous studies focus mainly on the blue water and often overlooked the green water (Cao et al., 2014; Falkemnark, 1995). Furthermore, the previous studies main ly focused on the basin scale. County-level studies were rare. Meanwhile, little attention was paid to the controlling factors of blue water and green water flows. In practice, there is a need for decision makers to understand the hydrological dynamics in each county. Therefore, the dynamics of blue water and green water flows on the county scale and their controlling factors deserve further investigation.

Dynamic analysis is extremely vital for the research in hydrology and meteorology, especially under the circumstance of global change (Karpouzos et al., 2010; Lopes and Machado, 2014). Generally, scenario analyses based on the hydrological model and statistical test were two popular methods among many others. Scenario analysis method displayed many advantages in predicting the future variation because of using the hydrological models, Such as river discharge (Schneider et al., 2013), runoff (Piao et al., 2007). And the statistics were usually used to describe past dynamic (Feidas et al., 2004; Kundzewiczet al., 2008; Sen, 1968). Meanwhile, it's also quite vital to identify the driver of hydrological variation from the view of regional water resource management (Page et al., 2010). However, previous trend analysis has mainly focused on runoff, which is a type of blue water flow (Blahusiakova and Matouskova, 2015; Hu et al., 2013; Liu et al., 2013), and potential evapotranspiration (Abtew et al., 2011; Li et al., 2015; Ye et al., 2013). It is very necessary to develop a hybrid dynamic detect approach that combines hydrological model and statistical methods based on their merits.

The Heihe River basin, the second largest inland river basin of China, was chosen as the experimental sit (Figure. 1). This basin with the fragile eco - environment has suffered serious water scarcity and endangered the safety of ecosystem and human (Wang et al., 2010). Effective management of water resources is a crucial need in this basin. To achieve this aim, detailed and re liable information for each county of water flows is indispensable (Chen et al., 2006). Previous studies main ly focus on the dynamics of basin meteorological variables and runoff (Chen et al., 2010; Cheng et al., 2015; Li et al., 2011; Sang et al., 2014), and they rarely related to the green water and blue water flows. Therefore, we tried to analyze the dynamics and controlling factors of green and blue water on the county scale in this basin. 

above-mentioned variables on county scale 2) to identify their controlling factors in each county.

\section{Methods}

\subsection{Study area}

5 The Heihe River Basin (HRB) lies within $38-42^{\circ} \mathrm{N}$ and $98-101^{\circ} \mathrm{W}$ in Northwest China and covers an area of $14.31 \times 10^{5} \mathrm{~km}^{2}$ (Wu et al., 2013). Mean elevation is surpassed $1200 \mathrm{~m}$ and the range was $879-5573 \mathrm{~m}$. The HRB comprises eleven counties which are the Qilian, Sunan, Gnazhou, Shandan, Suzhou, Mingle, Linze, Gaotai, Jinta, Jiayuguan, Ejilaqi. The upper HRB includes Qilian and Sunan county and the middle HRB includes Gnazhou, Shandan, Suzhou, Mingle, Linze, Gaotai county. The down HRB was consist of Jinta and Ejilaqi county. The basin mean rainfall is $193.4 \mathrm{~mm} \mathrm{a}^{-1}$ from 1980 to 2009. Mean annual rainfall declined from the upper basin to down basin (Yin et al., 2015).

\subsection{Methods and data}

The green water flow refers to actual evapotranspiration (AE), and the blue water flow comprises surface runoff, lateral flows, and groundwater recharge (Schuol et al., 2008). Green water coefficient (GW C) -the proportion of green water in total flows (blue and green flowers, TW) was used to measure the importance of blue and green flows (Liu et al., 2009a).

The amount of flows was simulated by the Soil and Water Assessment Tool (SWAT), which has successfully been applied to many countries and regions (Baker and Miller, 2013; Li et al., 2010; Schuol et al., 2008; Zende and Nagarajan, 2015). The Nash-Sutcliffe efficiency coefficient (NS), determination coefficient $\left(R^{2}\right)$ and root mean square error (RMSE) -observations standard deviation ratio (RSR) was used to estimate the model simulation. Generally, model simulation is perfect when RSR range is between 0.00 and 0.50 , and NS range is between 0.75 and 1.00 . The simulation effect is good when the range of RSR is from 0.50 to 0.60 and NS is from 0.65 to 0.75 . The simulation effect is satisfactory when RSR belongs to $0.60-0.70$ and NS belongs to $0.50-0.65$ (Krause et al., 2005; Moriasi et al., 2007). One this base, we further assessed the accuracy of simulated green water by observed AE in the year of 2007.

In this study, land-use data come from the Chinese Academy of Sciences (CAS) Environmental Data Center. Monthly average discharge was obtained from the HRB Water Resources Administration. Daily climate data were from 16 weather

Soil data were from Harmonized World Soil Database version 1. 1 via the FAO website.

\subsection{Dynamic and controlling factor analysis}

The Mann-Kendall (MK) trend test was selected to describe trends of flows, and the sequential Mann-Kendall (SMK) (Ahmad et al., 2015a; Ahmad et al., 2015b; da Silva et al., 2015) was chosen to identify abrupt variations. The MK test is 

DC >0.50 (Bin et al., 2003; Nagelkerke, 1991). Figure. 2 listed the flowchart of our study.

\section{Results}

\subsection{Model calibration and uncertainty analysis}

The agreement between simulated and observed monthly discharge values in the periods of calibration and validation was excellent (Figure. 3). All NS and $\mathrm{R}^{2}$ values were above 0.5 , and absolute $S R S$ values were below 25 (Table 1). These suggest model perform fairly well, in spite of small differences sometimes (Figure. 3). The results simulated by SWAT models can be applied to evaluate green water and blue water flows.

We used the observed annual AE in 2007 (Yang, 2009) to further estimate the green water flow due to the limitation of observed data. The range of relative errors is from $3.51 \%$ to $5.78 \%$ (Table 2).

\subsection{Dynamics of blue water flow}

In the Qilian (Figure. 4a), Sunan (Figure. 4c), Gan zhou (Figure. 4e) and Mingle counties (Figure. 4g), the blue water flow increased from 1980 to 2009, although it was not significant. However, blue water flow at the Linze (Figure. 4k), Suzhou (Figure. $4 \mathrm{~m}$ ) and Gaotai counties (Figure. 4q) decreased significantly during this period $(\mathrm{p}<0.01)$. Blue water flow increased by $0.13,0.68$ and 0.55 per decade from 1980 to 2009 at the Linze, Suzhou and Gaotai counties, respectively. Meanwhile, the blue water flow increased significantly in Shandan county $(\mathrm{p}<0.05)$, whe reas decreased significantly at Jinta county $(\mathrm{p}<0.05)$.

Based on the SMK test (Figure. 4), all the abrupt changes of blue water flow changed abruptly were mainly in the 1980s and especially 2000s except Gaotai county (Figure. 4r). The abrupt change over 2000s happened around 2000-2003, flow at the Mingle (Figure. 4m) and Shandan counties (Figure. 4j) changed abruptly in 2001.

\subsection{Dynamics of green water flow}

In the upper basin including the Qilian county (Figure. 5a), the green water flow generally increased significantly from 1980 to 2009 ( $\mathrm{p}<0.01$ ). Green water flow at Qilian county and Sunan county (Figure. $5 \mathrm{c}$ ) increased by $1.32 \times 10^{8} \mathrm{~m}^{3}$ and $0.13 \times 10^{8}$ $\mathrm{m}^{3}$ per decade from 1980 to 2009 , respectively. The blue water also generally increased in the middle-stream counties, 
significantly at Ganzhou (Figure. 5e), Sunan and Shandan (Figure. 5j) counties ( $<<0.01$ at Gan zhou county and $\mathrm{p}<0.05$ at Shandan and Sunan counties). Blue water flow at Jiayuguan (Figure. 5o)) showed a weak decreasing trend from 1980 to 2009 (Figure. 5), versus an increasing trend at other ten counties. Blue water flow at the Ejilaqi (Figure. 5u) county in the downstream basin has a significant increasing trend from 1980 to 2009 ( $\mathrm{p}<0.01)$. 5r)) and Ejilaqi (Figure. 5v) counties changed abruptly in 2001, 2003, 2003, 2001, 2001 and 1985, respectively (Figure. 5). It changed abruptly in 1996, 2001 and 2005 at Jita county (Figure. 5t), and in 1982 and 2005 at Jiayuguan county. It changed abruptly in 1983, 1986 and 1993 at Suzhou county (Figure. 5n). However, there were always abrupt changes followed 2000, around 2000-2003. Meanwhile, in the study period blue water flow has different trends. For example, at the Linze county (Figure. 5l), blue water flow increased from 1980 to 1982, decreased from 1982 to 1985, and then increased from 1985 to 1995, decreased from 1995 to 2001, and decreased from 2001 to 2004, and finally increased from 2004 to 2009.

The GWC generally decreased from 1980 to 2009 at Qilian, Suzhou, Shandan, Linze and Gaotai counties, but insignificantly. Meanwhile, the GWC increased at Mingle, Sunan, Jinta, Jiayuguan and Ganzhou counties (Table 3). The dynamics of GWC generally are same as those of green water flow, although not completely consistent. The reason for this is that the GWC depend on green water flow and total flows, not only green water flow.

\subsection{Dynamics of total flow}

The trends in the blue water, green water, and total flows showed a considerable spatial variation among the counties. The MK test showed that total flows generally increased in nine counties, including the Su zhou, Shandan, Qilian, Mingle, Lin ze, Sunan, Gaotai and Ejilaqi (Table 4). The increase was significant in Mingle, Gaotai and Gan zhou from 1980 to 2009 (p < 0.05; Table 4). The largest increase was in the Ejilaqi county, where total flow increased by $6.17 \times 10^{8} \mathrm{~m}^{3}$ from 1980 to 2009 , equivalent to a rate of increase of $2.08 \times 10^{8} \mathrm{~m}^{3}$ per decade. This was caused by an increase in green water flow (Figure. 5). However, the total flows at Jinta, and Jiayuguan decreased insignificantly in the past three decades (Table 4). This is mainly attributed to decrease in blue water flow (Figure. 4). Blue water flow decreased at Jinta and Jiayuguan by $0.07 \times 10^{8}$ $\mathrm{m}^{3}$ per decade and $0.33 \times 10^{8} \mathrm{~m}^{3}$ per decade, respectively (Figure. 4 ).

\subsection{Predicted trends in blue water, green water and total flows in the future}

In the upstream including the Qilian county (Figure. 6a), the hydrological variables have insistent trends in the future, with $\mathrm{H}>0.50$ (Figure. 6). The strength of the persistence of trends in descending order is: green water flow $>$ total flow > GW C >blue water flow. All the variables have strong persistent trends, will keep increasing in the upstreambasin.

In midstream basin, including Sunan (Figure. 6b), Gan zhou (Figure. 6c), Mingle (Figure. 6d), Shandan (Figure. 6e), Linze 
persistent future trends, with $\mathrm{H}>0.5$ (Figure. 6). This indicates that the blue water flow, green water flow, total flow and GW C will keep increasing. At Jiayuguan, Sunan and Jinta county, the Hurst index of blue water flown were close to the value of 1.00 , suggesting that persistent trends are obvious, and the blue water flow in both counties should continue to decrease in future. However, the hydrological variables at Shandan county do not have an obvious persistent trend with the Hurst index of green water flow and total flow closing to 0.50 , which represents quite independent trends.

In the downstream basin, including Jinta and Ejilaqi counties, the trend for blue water flow has an obviously persistent change in the future, with $\mathrm{H}=0.99$ at Jinta county (Figure. $6 \mathrm{j}$ ) and $\mathrm{H}=0.98$ at Ejilaqi county (Figure. 6k). This means that the blue water flow may quickly decrease in the future. The Hurst indexes for the Green water flow, total flow and GW C also have persistent future trends, with $\mathrm{H}>0.5$. This implies that those hydrological variables will increase in the downstream basin. The most persistent change trends display in the downstream basin.

All of Hurst index values of blue water flow were surpassed 0.5 , which indicates that the trends in the past were likely to continue (Figure. 6) The counties including Qilian, Sunan, Ganzhou, Shandan, Mingle, Linze, Suzhou and Ejilaqi have persistent trends and will keep increasing in the future, whereas blue water flow at Jiayuguan and Jinta counties may decrease in the future inconsistent with the past trend.

For eleven counties in the HRB, the blue water flow, green water flow, total flows, and GW $\mathrm{C}$ generally have continuous future trends as in the past, with $\mathrm{H}>0.5$ (Figure. 6), especially in the upper and middle HRB.

\subsection{Controlling factors for dynamics of bl ue water, green water and total flows}

For the blue water flow, the trends and influence factors differ for different counties of the river basin among eleven count ies. One reason for this is that rainfall generally increased and temperature significantly increased during this period (Table 5 and

Figure. A1). We detected that rainfall was the controlling factor at Qilian, Sunan and Shandan county (Table 6, DC $=0.90$ at Qilian and DC=0. 81 at Shandan), where their general trends and the fluctuations were closely related to their variations of rainfall (Figure. A1). Rainfall contributed more to blue water flow than the temperature in Mingle, Linze, Jiayuguan and Ganzhou. By contrast, the contribution of temperature was more than that of rainfall in Suzhou, Jinta, Gaotai, Ejinaqi. However, neither the rainfall nor the temperature was the main controlling factor in these nine counties (Table 5). Human activities may be the mainly driver for land-use change.

For the green water, obviously, our analysis showed that the controlling factor was the rainfall with all DC $>0.84$ during the period of 1980-2009 (Table 6). This controlling action of rainfall is extremely obvious in Linze, Jinta, Gaotai and Ejilaqi counties with DC>0.90.

\section{Discussion}

The blue water for counties in the HRB generally increased from 1980 to 2009, although the blue water flow at Jiyuguan 

the whole basin, where the rainfall was generally high. An increase in rainfall led to a fast increase in runoff (Li et al., 2011). The barrier effect of the Qilian Mountains in the upstream basin had caused different regional hydrological cycles and different rainfall sources (Jia et al., 2008). Rainfall in upstream was influenced by different atmospheric circulations that resulted from local topography, i.e. the West Pacific Subtropical High and by the Indian Ocean Southwest Monsoon (Jia et al., 2008). The West Pacific Subtropical High and the Indian Ocean Southwest Monsoon began to change in the 1980s, leading to an abrupt change in rainfall in 1980s (Jia et al., 2008; Lan et al., 2001). In Shandan county, blue water flow increased significantly from 1980 to 2009. But they also fluctuated in different periods. The channeling effect at this county resulted in different regional hydrological cycles and rainfall sources (Lan et al., 2001). Hence, at Shandan, rainfall was influenced by different atmospheric circulations and topography (Lan et al., 2001). Rainfall there was mainly influenced by the Western Pacific Subtropical High and by the Eurasian Middle-High Latitude Circulation, which led to fluctuations of rainfall at Shandan county.

The land use change maybe the driver of blue water in Mingle, Linze, Jiayuguan, Ganzhou, Su zhou, Jinta, Sunan, Gaotai, Ejinaqi counties. Surface roughness, albedo and other properties that affected the exchange of water and energy between the earth surface and atmosphere could be altered by conversions of land use, resulting in variability of surface energy and net radiation (Kueppers and Snyder, 2012), and further influencing hydrological processes. Land use change, especially the expansion of agricultural land, had influenced on hydrological processes and water balance of Heihe River basin (Deng et al., 2015; Fu et al., 2014; Liu et al., 2010; Nian et al., 2014). The expansion of farmland had a significant influence on the shallow aquifer water system through intensive irrigation. W ith the expansion of farmland, ground water recharge increased due to enhanced infiltration in these counties (Wang et al., 2014). Deforestation also reduced soil water retention capacity and raise surface runoff (Zhou et al., 2002).

Climate will have a large influence on future blue water flow. Climate models predicted a weak increase in annual rainfall and significant increase in temperature (Dahe et al., 2002). Climate change is likely to cause annual runoff variation (Zhi et al., 2009) and increase surface runoff by more than 10\% during 2010-2050 (Dahe et al., 2002). An increase in rainfall will and low soil moisture content.

The green water depended mainly on water availability and air temperature in the northwest of China (Han et al., 2012; Yang and Yang, 2012). Since 1850, the temperature on the Earth's surface has been increasing continuously; climate warming is an obvious phenomenon (Stocker, 2014). In general, because of climate warming, the air near the earth's surface 

limited by water availability (Sun and $\mathrm{Wu}, 2001$ ). Green water was not strongly driven by temperature, but the rainfall, although there are significant changes in temperature in the study period. An increase in rainfall will increase surface runoff and soil moisture, leading to the increase in blue water flow (AE). In the Ganzhou county, both rainfall and te mperature have a positive influence, leading to increase in green water. The contribution of rainfall was much larger than that of temperature. However, in the Ganzhou county, the contributions of rainfall and temperature were low, and both were not the main driver. This suggests that human activities should be the controlling factor of green water in the Gan zhou county, which offset the positive influence induced by the increase of rainfall and temperature. Ganzhou county was the commodity grain base for the whole Gansu province and agriculture land depended on irrigation quite wild (Chen et al., 2006). For Gan zhou county, the rapid expansion of irrigation in the past three decades has significantly altered the energy budget at the land surface (W iss er et al., 2009). AE will change when irrigation related change in soil moisture, deep filtration and underground recharge (Wang et al., 2014). Our results indicate that green water flow will keep trend in the past, all the counties will increase expect Jiayuguan county where the future trend will decrease (Figure. 5o and $6 \mathrm{~h}$ ).

When green and blue water flows are summed, the trend in the total flow appears to reflect a combined influence of climate and human activities in the eleven counties in the HRB from 1980 to 2009 (Table 4). Because the green water flow was much more than blue water flow in the HRB, the general trends in total flow were similar to green water flow. It increased in Qilian, Ganzhou, Sunan, Suzhou, Linze, Gaotai, Shandan, Mingle and Ejilaqi counties, whereas decreased in Jinta and Jiayuguan counties. Meanwhile, our analysis showed the controlling factor of total flow at each county was different from that for green water flow: the total flow in the most counties was mainly influenced by rainfall (DC $>0.5$; Table 6), however, at Jinta and Jiayuguan county, the human activities were the major controlling factor. With increases in rainfall and temperature, the increase in blue water and green water flows lead to the increase in the total flow at Qilian, Ganzhou, Sunan, Suzhou, Linze, Gaotai, Shandan, Mingle and Ejilaqi counties. But the total flow decreased due to decrease in blue water flow and green water flow, which was induced by increases in rainfall and temperature at Jiayuguan county. Our results also showed that the decrease in blue water flow and green water flow at Jinta county would increase blue water for total flow in the eleven counties, which is consistent with the trend in green water driven by rainfall expect Jinta and Jiayuguan counties $(\mathrm{H}>0.5$, Figure. 6).

There are variations in the dynamic and controlling factor of the GWC in different counties in the HRB (Table 5 and 6). For all of the counties, the temperature was not the controlling factor and the contribution of rainfall to the GWC is relatively higher. The GWC increase induced by green water rapidly rise with the increase of rainfall and temperature in Linze, Suzhou, 
Shandan, Ejilaqi county. The increase of rainfall and temperature in the Jiayuguan and Jinta county would increase runoff (blue water) more than evapotranspiration (green water), leading to a lower GWC. For Qilian, Suzhou, Shandan, Jinta, Jianyuan and Ejilaqi counties, the rainfall determined the trends and variability of the GWC. All the Hurst index values surpassed 0.50 , indicating the GW C depend on the past trend and will keep the trend in the future.

Hence, the rainfall exerted the most influence on three flows in the HRB. The different dynamic of three flows formed caused by different generation mechanisms of rainfall on the county scale. Therefore, the abrupt changes of temperature and rainfall could have influenced both the blue water and total flows. Moreover, the flows are not only influenced by atmospheric circulation, but also by local human activities, such as the blue water flow of Mingle, Linze, Jiayuguan and Ganzhou counties. The quantitative impacts of human activities in each county will also need further research. The similar abrupt changes in the water flows, rainfall, and temperature reflect the close relationship between these three parameters in the eleven counties.

At the county level, different rainfall patterns also can lead to different hydrological processes. For example, the rainfall decreased in Shandan county significantly $(\mathrm{P}<0.05)$, but increased in Mingle county. However, the difference caused the blue water flow to increase in both counties (significantly for Shandan county, and insignificantly for Mingle county). In the future, the three flows will have an increasing trend due to the projected increase of rainfall.

The dynamic of the climate can largely explain the variations and abrupt changes of three flows in different periods (Table A 1and Figure. A 1). However, there are some abrupt changes in the 1990s and 2000s, which were close to 1992, 1997 and 2000 when rainfall and temperature had no abrupt changes in the corresponding periods. These abrupt changes should be attributed to the China's water transport project "Heihe River basin allocation policy" initiated in 1992,1997 and 2000 to ensure the enough water availability and in case of drying up of Dongjuyanhai Lake. The water transport project makes an influence on green water flow and blue flown mainly though changing the underground water level and surface water. "Heihe River basin allocation policy in 2000 had decreased ground water level by $1.3-2.7 \mathrm{~m}$ in the middle HRB (Haiyang et al., 2007) and raised it by $0.4-0.6 \mathrm{~m}$ in the down HRB (Zhi et al., 2007). Yinchun et al (2014) indicated the water transport project deceased the number of water withdrawal gates by $26 \%$, reduced the blue water withdrawal by $1.05 \times 10^{9} \mathrm{~m}^{3}$ and increased the underground water exploitation by $1.64 \times 10^{9} \mathrm{~m}^{3}$ in the whole Heihe River basin (Yinchun et al., 2014). In the middle-stream, "Heihe River basin allocation project" in 2000 induced the decrease the underground water level in the irrigation region caused by the reduction of exchange of surface and underground water, and expansion of the underground water exp loitation (Zhi et al., 2008).

This study has some limitations. First, more data need to be obtained and complemented, such as the hydrological data in 
We investigated the dynamic of water flows and GWC in the HRB by five statistical tests with SWAT model on the county scale. We further detected the controlling factor for these trends for each county.

(1) For the Qilin, Suzhou, Shandan, Mingle, Linze, Gaotai, Gan zhou, Sunan and Ejilaqi counties, the blue water, green and total flows have increased from 1980 to 2009 and these trends were significant in above-mentioned counties, especially for the blue water flow. For the Jiayuguan county, the blue water, green and total flows have decreased from 1980 to 2009. For the Jinta county, green water and total water flows have decreased from 1980 to 2009 , whereas the blue water had a weak increase trend. The GWC presented some decrease in Qilian, Suzhou, Shandan, Linze, Gaotai county, and an increasing trend was found in the Mingle, Sunan, Jinta, Jiayuguan, Gan zhou and Ejilaqi counties. In all the counties in the HRB, three flows and GWC have persistent future trends and the strength generally were qu ite large, especially in the Sunan and Ejilaqi counties.

(2) These trends are ascribed mainly to rainfall due to the limitation of water availability in the semiarid HRB. At Qilian and Shandan counties, rainfall was the controlling factor of the blue water flow, green water flow, total flow and GW C. At Mingle, Linze and Gaotai counties, the Green water and total flows were determined by rainfall. At Suzhou county, the trends of green water flow and GWC mainly were controlled by rainfall. At the Jinta and Ejilaqi county, the variation of green water flow, total flow and GWC mainly were driven by rainfall. Meanwhile, the human activities, especially land use change, appear to be the dominating cause of these trends of tree flow and GWC in Shandan county. However, the quantitative influences of anthropogenic activities will need further study.

(3) The abrupt changes in the three water flows and in GWC were mainly affected by the China's water transport project "Heihe River basin allocation project" respectively initiated in 1992,1997 and 2000, although rainfall and temperature make some influences, especially in the 1980s. "Heihe River basin allocation project" has an important influence on the hydrological processes and three water flows in the HRB.

(4) This study showed the past and future dynamic of hydrological variable for eleven counties in the HRB and their controlling factors, which can improve the understanding of human and in favor of water resource s management for the decision makers. More attention should be paid into the counties where the water availability and GWC declined. Thus, this study provides the reference for further studies on the county scale in similar regions and basin. Variations in the 
Hydrol. Earth Syst. Sci. Discuss., doi:10.5194/hess-2016-241, 2016

Manuscript under review for journal Hydrol. Earth Syst. Sci.

Published: 13 June 2016

(c) Author(s) 2016. CC-BY 3.0 License.

dynamic and controlling factors in different counties suggested decision maker should adopt different policies in different counties in the basin.

\section{Acknowledgements}

Funding for this study was provided by the project of China Natural Science No.91325302. The data for this paper are available at the websites, official publication and publication referenced in the text.

\section{References:}

Abtew, W., Obeysekera, J., and Iricanin, N.: Pan evaporation and potential evapotranspiration trends in South Florida, Hydrol Process, 25, 958-969, 2011.

Ahmad, I., Tang, D., Wang, T., Wang, M., and Wagan, B.: Precipitation Trends over Time Using Mann-Kendall and Spearman's rho Tests in Swat River Basin, Pakistan, Advances in Meteorology, doi: Artn 431860

10.1155/2015/431860, 2015a. 2015a.

Ahmad, I., Tang, D., Wang, T., Wang, M., and Wagan, B.: Precipitation Trends over Time Using Mann-Kendall and Spearman's rho Tests in Swat River Basin, Pakistan, Advances in Meteorology, 2015, 1-15, 2015b.

Bae, D. H., Jung, I. W., and Chang, H.: Long-term trend of precipitation and runoff in Korean river basins, Hydrol Process, 22, 2644-2656, 2008.

Baker, T. J. and Miller, S. N.: Using the Soil and Water Assessment Tool (SWAT) to assess land use impact on water resources in an East African watershed, Journal of Hydrology, 486, 100-111, 2013.

Bin, S., Tao, H., and Qian, Q.: SPSS statistical analysis, Mechanicaal Industry Press, Beijing, 2003.

Blahusiakova, A. and Matouskova, M.: Rainfall and runoff regime trends in mountain catchments (Case study area: the upper Hron River basin, Slovakia), J Hydrol Hydromech, 63, 183-+, 2015.

Cao, X. C., Wu, P. T., Wang, Y. B., and Zhao, X. N.: Assessing blue and green water utilisation in wheat production of China from the perspectives of water footprint and total water use (vol 18, pg 3165, 2014), Hydrol Earth Syst Sc, 18, 3205-3205, 2014.

Chen, C., Hagemann, S., and Liu, J. G.: Assessment of impact of climate change on the blue and green water resources in large river basins in China, Environ mental Earth Sciences, 74, 6381-6394, 2015.

Chen, J., Wu, X. D., Finlayson, B. L., Webber, M., Wei, T. Y., Li, M. T., and Chen, Z. Y.: Variability and trend in the hydrology of the Yangtze River, China: Annual precipitation and runoff, Journal of Hydrology, 513, 403 -412, 2014.

Chen, L. A., Zhao, C. Y., and Feng, Z. D.: Regional Climate Responses to the Land Use and Land Cover Change in Heihe River Basin, China, 2010 Ieee International Geoscience and Remote Sensing Sy mposium, doi: 10.1109/Igarss.2010.5651295, 
Chen, Z. Y., Nie, Z. L., Zhang, G. H., Wan, L., and Shen, J. M.: Environmental isotopic study on the recharge and residence time of g roundwater in the Heihe River Basin, northwestern China, Hydrogeology Journal, 14, 1635 -1651, 2006.

Cheng, A. F., Feng, Q., Fu, G. B., Zhang, J. K., Li, Z. X., Hu, M., and Wang, G.: Recent Changes in Precipitation Extremes in the Heihe River basin, Northwest China, Adv Atmos Sci, 32, 1391-1406, 2015.

5 Cheng, Y.-f., Wang, G.-X., Xi, H.-y., and Wang, J.-d.: Variations of land evapotranspiration in the plain of the middle reaches of Heihe River in the recent 35 years, Journal of Glaciology and Geocryology, 29, 406-412, 2007.

Chukalla, A. D., Krol, M. S., and Hoekstra, A. Y.: Green and blue water footprint reduction in irrigated agriculture: effect of irrigation techniques, irrigation strategies and mulching, Hydrol Earth Syst Sc, 19, 4877-4891, 2015.

Cong, Z. T., Yang, D. W., and Ni, G. H.: Does evaporation paradoxexist in China?, Hydrol Earth Syst Sc, 13, 357 -366, 2009. da Silva, R. M., Santos, C. A. G., Moreira, M., Corte-Real, J., Silva, V. C. L., and Medeiros, I. C.: Rainfall and river flow trends using Mann-Kendall and Sen's slope estimator statistical tests in the Cobres River basin, Nat Hazards, 77, 1205-1221, 2015.

Dahe, Q., Yhui, D., Shaowu, W., Gangrong, D., Erda, L., and Chunzhen, L.: A st udy of environment change and its impacts in western China, Ear th Science Frontiers, 9, 322-327, 2002.

Deng, X. Z., Shi, Q. L., Zhang, Q., Shi, C. C., and Yin, F.: Impacts of land use and land cover changes on surface energy and water balance in the Heihe River Basin of China, 2000-2010(T), Physics and Chemistry of the Earth, 79-82, 2-10, 2015.

Falkemnark, M.: Coping with Water Scarcity under Rapid Population Growth: paper for the conference of SADC water ministries. Pretoria, 1995.

Falkenmark, M. and Rockstrom, J.: The new blue and green water paradig m: Breaking new ground for water resources planning and management, J Water Res Pl-Asce, 132, 129-132, 2006.

Faramarzi, M., Abbaspour, K. C., Schulin, R., and Yang, H.: Modelling blue and green water resources availability in Iran, Hydrol Process, 23, 486-501, 2009.

Feidas, H., Makrogiannis, T., and Bora-Senta, E.: Trend analysis of air temperature time series in Greece and their relationship with circu lation using surface and satellite data: 1955-2001, Theor Appl Climatol, 79, 185-208, 2004.

Fu, L., Zhang, L. H., and He, C. S.: Analysis of Agricultural Land Use Change in the Middle Reach of the Heihe River Basin, Northwest China, Int J Env Res Pub He, 11, 2698-2712, 2014.

Haiyang, X., Qin, F., and Jianhua, S.: Influence of water transport project on groundwater level at lower reaches of the Heih e River, Arid Land Geography, 30, 2007.

Han, S. J., Xu, D., and Wang, S. L.: Decreasing potential evaporation trends in China from 1956 to 2005: Accelerated in regions with significant agricultural influence?, Agricultural and Forest Meteorology, 154, 44 -56a, 2012. 
Hu, C. H., Cao, B., Gao, Z. Q., and Wu, Z. N.: An Assessment of Runoff Trends in Fenhe Catch ment and Its Potential Cause, Proceedings of the 35th Iahr World Congress, Vols I and Ii, 2013. 3497-3508, 2013.

Jeuland, M. and Whittington, D.: Water resources planning under climate change: Assessing the robustness of real options for the Blue Nile, Water Resour Res, 50, 2086-2107, 2014.

5 Jewitt, G., Garratt, J., Calder, I., and Fuller, L.: Water resources planning and modelling tools for the assessment of land use change in the Luvuvhu Catchment, South Africa, Physics and Chemistry of the Earth, Parts A/B/C, 29, 1233-1241, 2004.

Jia, W.-X., He, Y.-Q., Li, Z.-X., PANG, H.-X., YUAN, L.-L., NING, B.-Y., SONG, B., and ZHANG, N.-N.: Regional characteristics of climatic change trend and break during last 50 y ears in Hexi Corridor, Sci. Geogr. Sinic a, 28, 525-531, 2008.

Karpouzos, D., Kavalieratou, S., and Babajimopoulos, C.: Trend analysis of precipitation data in Pieria Region (Greece), European Water, 30, 31-40, 2010.

Krause, P., Boyle, D. P., and Bäse, F.: Comparison of different efficiency criteria for hydrological model assessment, Advances in Geosciences, 5, 89-97, 2005.

Kueppers, L. M. and Snyder, M. A.: Influence of irrigated agriculture on diurnal surface energy and water fluxes, surface

Kundzewicz, Z. W., Mata, L. J., Arnell, N. W., Doll, P., Jimenez, B., Miller, K., Oki, T., Sen, Z., and Shiklomanov, I.: The implications of projected climate change for freshwater resources and their management, Hydrolog Sci J, 53, 3-10, 2008.

Lan, Y., Kang, E., Zhang, J., and Chen, R.: Air temperature series and its changing trends in Qilian Mountains area since 1950s, Journal of Desert Research, 21, 53-57, 2001.

Li, B., Chen, F., and Guo, H. D.: Regional complexity in trends of potential evapotranspiration and its driving factors in the Upper Mekong River Basin, Quatern Int, 380, 83-94, 2015.

Li, C., Li, W., Wang, X., Yang, W., and Yang, Z.: Characteristic changes in air temperature, precipitation and mountain runoff in the past 50 years in the middle and western reaches of Heihe river basin, J. Lanzhou Univ.(Natural Sciences), 4, 7-13, 2011.

Li, Z. L., Shao, Q. X., Xu, Z. X., and Cai, X. T.: Analysis of parameter uncertainty in semi-distributed hydrological models using bootstrap method: A case study of SWAT model applied to Yingluoxia watershed in northwest China, Journal of Hydrology, 385, 76-83, 2010.

Liu, J. G., Zehnder, A. J. B., and Yang, H.: Global consumptive water use for crop production: The importance of green water and virtual water, Water Resour Res, 45, 2009a. 

1988-2012, 2013.

Liu, W., Cao, S. K., Xi, H. Y., and Feng, Q.: Land use history and status of land desertification in the Heihe River basin, Nat Hazards, 53, 273-290, 2010.

5 Liu, X.-f., Ren, L., Yuan, F., Singh, V., Fang, X., Yu, Z., and Zhang, W.: Quantifying the effect of land use and land cover changes on green water and blue water in northern part of China, Hydrol Earth Syst Sc, 13, 735-747, 2009b.

Lopes, A. M. and Machado, J. A. T.: Dynamic Analysis and Pattern Visualization of Forest Fires, Plos One, 9, 2014.

Moriasi, D. N., Arnold, J. G., Van Liew, M. W., Bingner, R. L., Harmel, R. D., and Veith, T. L.: Model evaluation guidelines for systematic quantification of accuracy in watershed simulations, T Asabe, 50, 885-900, 2007.

Nagelkerke, N. J.: A note on a general definition of the coefficient of determination, Bio metrika, 78, 691-692, 1991.

Nian, Y. Y., Li, X., Zhou, J., and Hu, X. L.: Impact of land use change on water resource allocation in the middle reaches of the Heihe River Basin in northwestern China, Journal of Arid Land, 6, 273-286, 2014.

Page, M., Trustrum, N., Orpin, A., Carter, L., Gomez, B., Cochran, U., Mildenhall, D., Rogers, K., Brackley, H., and Palmer, A.: Storm frequency and magnitude in response to Holocene climate variability, Lake Tutira, North-Eastern New Zealand, Mar Geol, 270, 30-44, 2010.

Piao, S. L., Ciais, P., Huang, Y., Shen, Z. H., Peng, S. S., Li, J. S., Zhou, L. P., Liu, H. Y., Ma, Y. C., Ding, Y. H., Friedlingstein, P., Liu, C. Z., Tan, K., Yu, Y. Q., Zhang, T. Y., and Fang, J. Y.: The impacts of climate change on water resources and agriculture in China, Nature, 467, 43-51, 2010.

Piao, S. L., Friedlingstein, P., Ciais, P., de Noblet-Ducoudre, N., Labat, D., and Zaehle, S.: Changes in climate and land use have a larger direct impact than rising CO2 on global river runoff trends, P Natl Acad Sci USA, 104, 15242-15247, 2007.

Qiao, L., Hong, Y., McPherson, R., Shafer, M., Gade, D., Williams, D., Chen, S., and Lilly, D.: Climate Change and Hydrological Response in the Trans-State Oologah Lake Watershed-Evaluating Dynamically Downscaled NARCCAP and Statistically Downscaled CMIP3 Simu lations with VIC Model, Water Resour Manag, 28, 3291-3305, 2014.

Ravazzani, G., Ghilardi, M., Mendlik, T., Gobiet, A., Corbari, C., and Mancini, M.: Investigation of Climate Change Impact One, 9, 2014.

Rost, S., Gerten, D., Bondeau, A., Lucht, W., Rohwer, J., and Schaphoff, S.: Agricultural green and blue water consumption and its influence on the global water system, Water Resour Res, 44, 2008.

Sang, Y. F., Wang, Z. G., Liu, C. M., and Yu, J. J.: The impact of changing environments on the runoff regimes of the arid 
Schuol, J., Abbaspour, K. C., Yang, H., Srinivasan, R., and Zehnder, A. J. B.: Modeling blue and green water availability in Africa, Water Resour Res, 44, 2008.

Stocker, T. F.: Climate change 2013: the physical science basis: Working Group I contribution to the Fifth assessment report of the Intergovernmental Panel on Climate Change, Cambridge University Press, 2014.

Sulser, T. B., Ringler, C., Zhu, T., Msangi, S., Bryan, E., and Rosegrant, M. W.: Green and blue water accounting in the Ganges and Nile basins: Implications for food and agricultural policy, Journal of Hydrology, 384, 276 -291, 2010.

Sun, L. and Wu, G. X.: Influence of land evapotranspiration on climate variations, Sci China Ser D, 44, 838-846, 2001.

Wang, H. Y., Xie, Y. W., and Wu, Y. Y.: Dynamic Analysis of Landscape Changes in the Heihe River Basin Using Remote Sensing and GIS, 2010 18th International Conference on Geoinformatics, 2010. 2010.

Wang, P., Yu, J. J., Pozdniakov, S. P., Grinevsky, S. O., and Liu, C. M.: Shallow groundwater dynamics and its driving forces in extremely arid areas: a case study of the lower Heihe River in northwestern China, Hydrol Process, 28, 1539-1553, 2014.

Wu , W. Z., Tian, J., Zhao, C., Li, J. L., Gu, J., and He, C. S.: Multi-scale analysis of the long-term trend of the hydromeorological variablesin of the upper reach of the Heihe River,Northwest China, Marine Geology and Quaternary Geology, 33, 37-44, 2013.

Xu, Z. X. and Zuo, D. P.: Simulation of blue and green water resources in the Wei River basin, China, Evolving Water Resources Systems: Understanding, Predicting and Managing Water-Society Interactions, 364, 486-491, 2014.

Yang, H. B. and Yang, D. W.: Climatic factors influencing changing pan evaporation across China from 1961 to 2001, Journal of Hydrology, 414, 184-193, 2012.

Yang, Y. M.: Estimation of evapotranspiration in Heihe river basin based on remote sensing, 2009.Master degree thesis, Lan zhou University, Lan zhou University, Lan zhou, 21-56 pp., 2009.

Ye, X. C., Liu, J., and Zhang, Q.: Trends of estimated potential evapotranspiration in the Poyang Lake basin, China, Adv

Mater Res-Switz, 726-731, 3299-3302, 2013.

Yin, G. F., Li, J., Liu, Q. H., Li, L. H., Zeng, Y. L., Xu, B. D., Yang, L., and Zhao, J.: Improving Leaf Area Index Retrieval Over Heterogeneous Surface by Integrating Textural and Contextual Information: A Case Study in the Heihe River Basin, Ieee Geosci Remote S, 12, 359-363, 2015.

Yinchun, G., Xin, L., Wei, L., Yanlin, Z., Wenzhen, W., and Xiaoli, H.: The impacts of water delivery on artificial hydrological circulation system of the middle reaches of the Heihe River basin, Advances in Earth Science, 29, 285 -294, 
Hydrol. Earth Syst. Sci. Discuss., doi:10.5194/hess-2016-241, 2016

Manuscript under review for journal Hydrol. Earth Syst. Sci.

Published: 13 June 2016

(c) Author(s) 2016. CC-BY 3.0 License.
Hydrology and

Earth System

Sciences

Discussions

(c) (i)

2014.

Zende, A. M. and Nagarajan, R.: Sediment Yield Estimate of River Basin Using SWAT Model in Semi-arid Region of Peninsular India, Eng ineering Geology for Society and Territory, Vol 3: River Basins, Reservoir Sedimentation and Water Resources, doi: 10.1007/978-3-319-09054-2_110, 2015. 543-546, 2015.

Zhang, Y. G., Su, F. G., Hao, Z. C., Xu, C. Y., Yu, Z. B., Wang, L., and Tong, K.: Impact of projected climate change on the hydrology in the headwaters of the Yellow River basin, Hydrol Process, 29, 4379-4397, 2015.

Zhang, Y. Q., Leuning, R., Chiew, F. H. S., Wang, E. L., Zhang, L., Liu, C. M., Sun, F. B., Peel, M. C., Shen, Y. J., and Jung, M.: Decadal Trends in Evaporation from Global Energy and Water Balances, J Hydro meteorol, 13, 379-391, 2012.

Zhi, L., Wenzhao, L., and Xunchang, Z.: The impacts of future climate change on water resources in the Heihe Watershed on

the Loess Plateau, Acta Ecologica Sinica, 29, 3456-3464, 2009.

Zhi, W., Huijun, J., Yongchao, L., Xinglin, H., Jinkui, W., Sizhong, Y., and Yanjun, J.: Analysis of the change of groundwater resources due to water allocation in the irrigation areas of the middle Heihe River, Journal of Glaciology and Geocryology, 30, 345-349, 2008.

Zhi, W., Huijun, J., Yongchao, N., Sizhong, Y., Jinkui, W., and Shuzhou, W.: The effect on water env ironment in middle and downstream area of heihe river after water al location, Journal of Irrig ation and Drainage, 2006, 34-37, 2007.

Zhou, G. Y., Wei, X. H., and Yan, J. H.: Impacts of eucalyptus (Eucalyptus exserta) plantation on sediment yield in Guangdong Province, Southern China - a kinetic energy approach, Catena, 49, 231-251, 2002.

Zuo, D. P., Xu, Z. X., Peng, D. Z., Song, J. X., Cheng, L., Wei, S. K., Abbaspour, K. C., and Yang, H.: Simulating spatiotemporal variability of blue and green water resources availability with uncertainty analysis, Hydrol Process, 29,

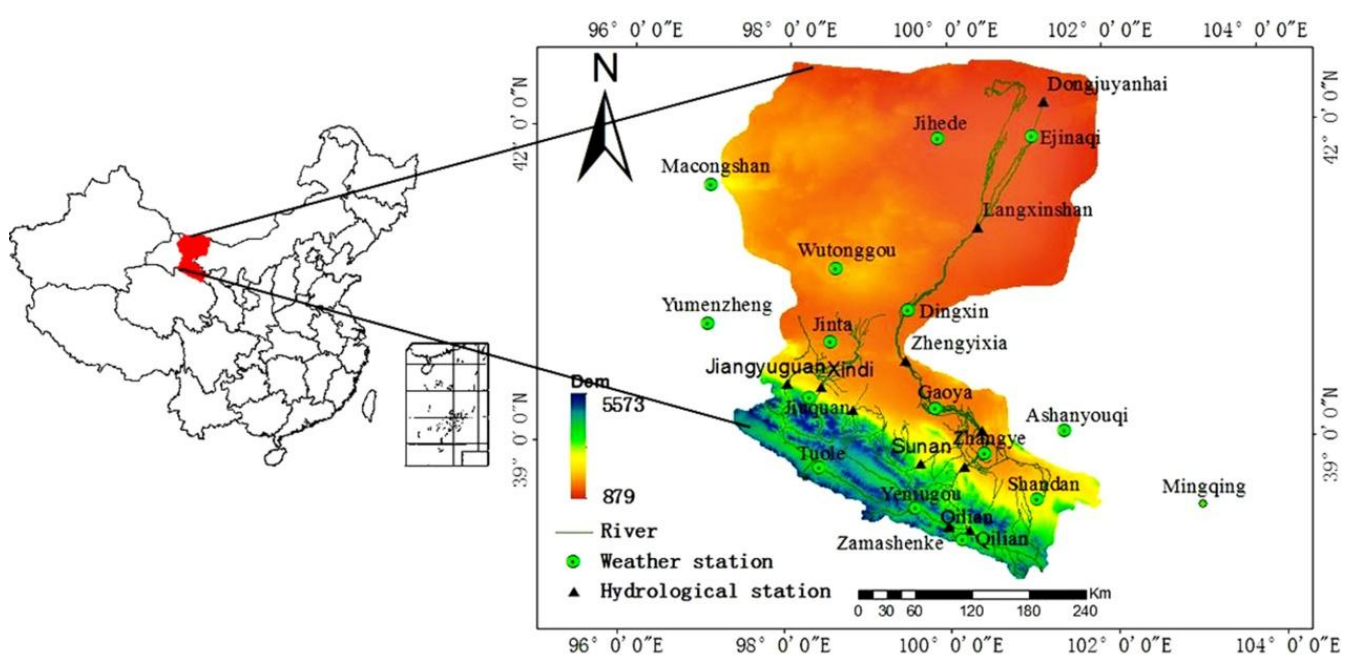


Hydrol. Earth Syst. Sci. Discuss., doi:10.5194/hess-2016-241, 2016

Manuscript under review for journal Hydrol. Earth Syst. Sci.

Published: 13 June 2016

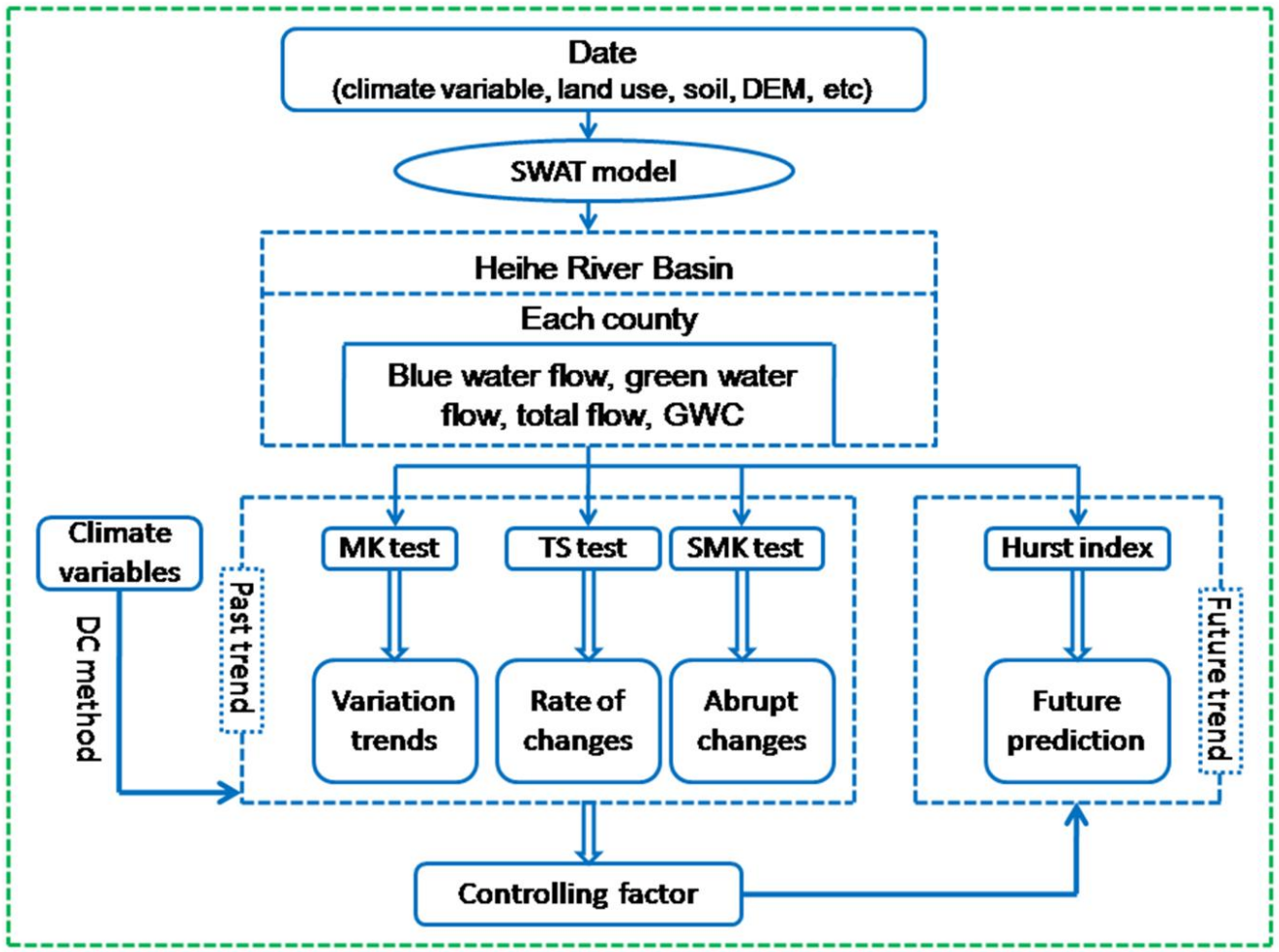

Figure 2: Flowchart of this study. Mann-Kendall test is represented by MK; SMK is Sequential Mann-Kendall test represented by SMK; 
Hydrol. Earth Syst. Sci. Discuss., doi:10.5194/hess-2016-241, 2016

Manuscript under review for journal Hydrol. Earth Syst. Sci.

Published: 13 June 2016
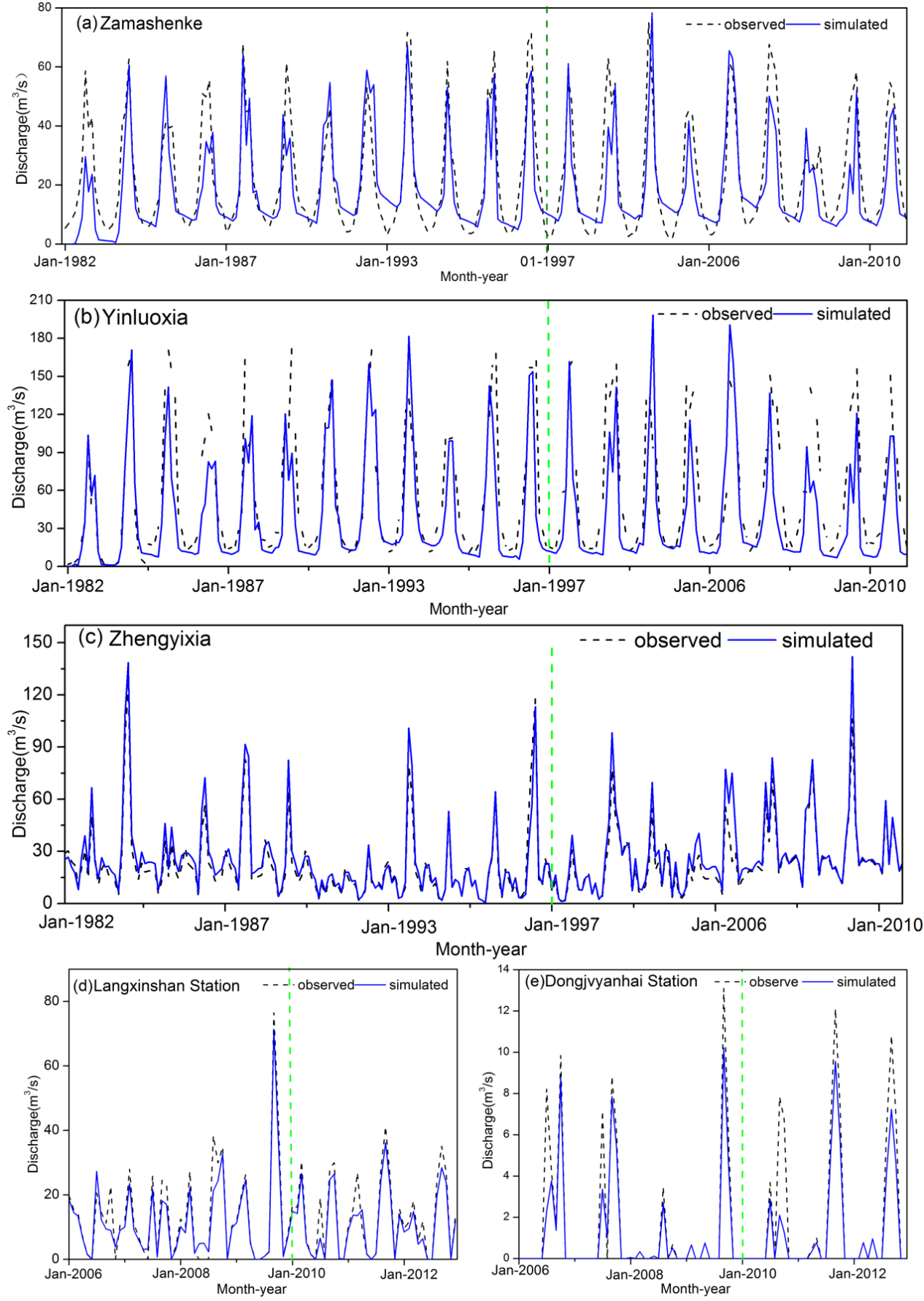

Figure 3: Monthly simulated and observed discharge in the Heihe River B asin during 1981-2010; Model validation period and calibration period of Zamashene (a), Yinluoxia (b), Zhengyixia (c) was respectively 1981-1997 and 1998-2012); Model validation period and calibration period of Langxinshan (d) and Dongjuy anhai (e) was respectively 2006-2010 and 2011-2012. 
Hydrol. Earth Syst. Sci. Discuss., doi:10.5194/hess-2016-241, 2016

Manuscript under review for journal Hydrol. Earth Syst. Sci.

Published: 13 June 2016

(c) Author(s) 2016. CC-BY 3.0 License.
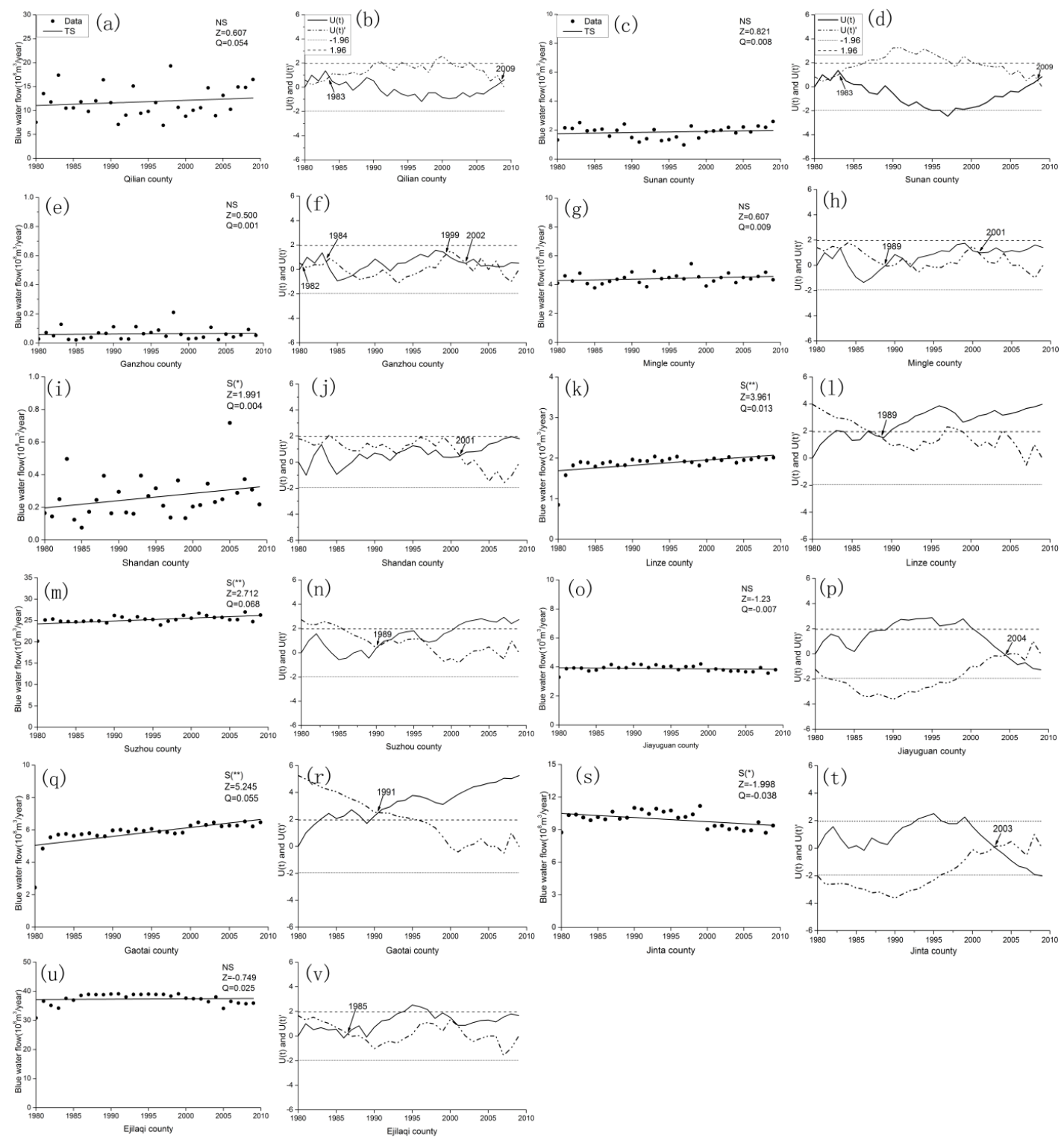

Figure 4: Dynamics of blue water flow at eleven counties of the Heihe River basin, including Qilian (a and b), Sunan (c and d), Ganzhou (e and f), Mingle (g and h), Shandan (i and j), Linze (k and l), Suzhou (m and n), Jiayuguan (o and p), Gaotai (q and r), Jinta (s and t) and Ejilaqi ( $u$ and v). Note: TS stands for the Theil-Sen test; $* * *$ indicates the significant level is at $\mathrm{p}<0.01 ;+$ indicates the significant level is at $\mathrm{p}<0 . \quad 05$; NS indicates the trend is not significant; $\mathrm{Z}>0$ indicates a downward trend and $\mathrm{Z}<0$ indicates an upward trend; $\mathrm{Q}$ stands for the change rate; $u(t)>u(t)$ ' denotes increase, while $u(t)<u(t)$ ' denotes decrease. 
Hydrol. Earth Syst. Sci. Discuss., doi:10.5194/hess-2016-241, 2016

Manuscript under review for journal Hydrol. Earth Syst. Sci.

Published: 13 June 2016

(c) Author(s) 2016. CC-BY 3.0 License.
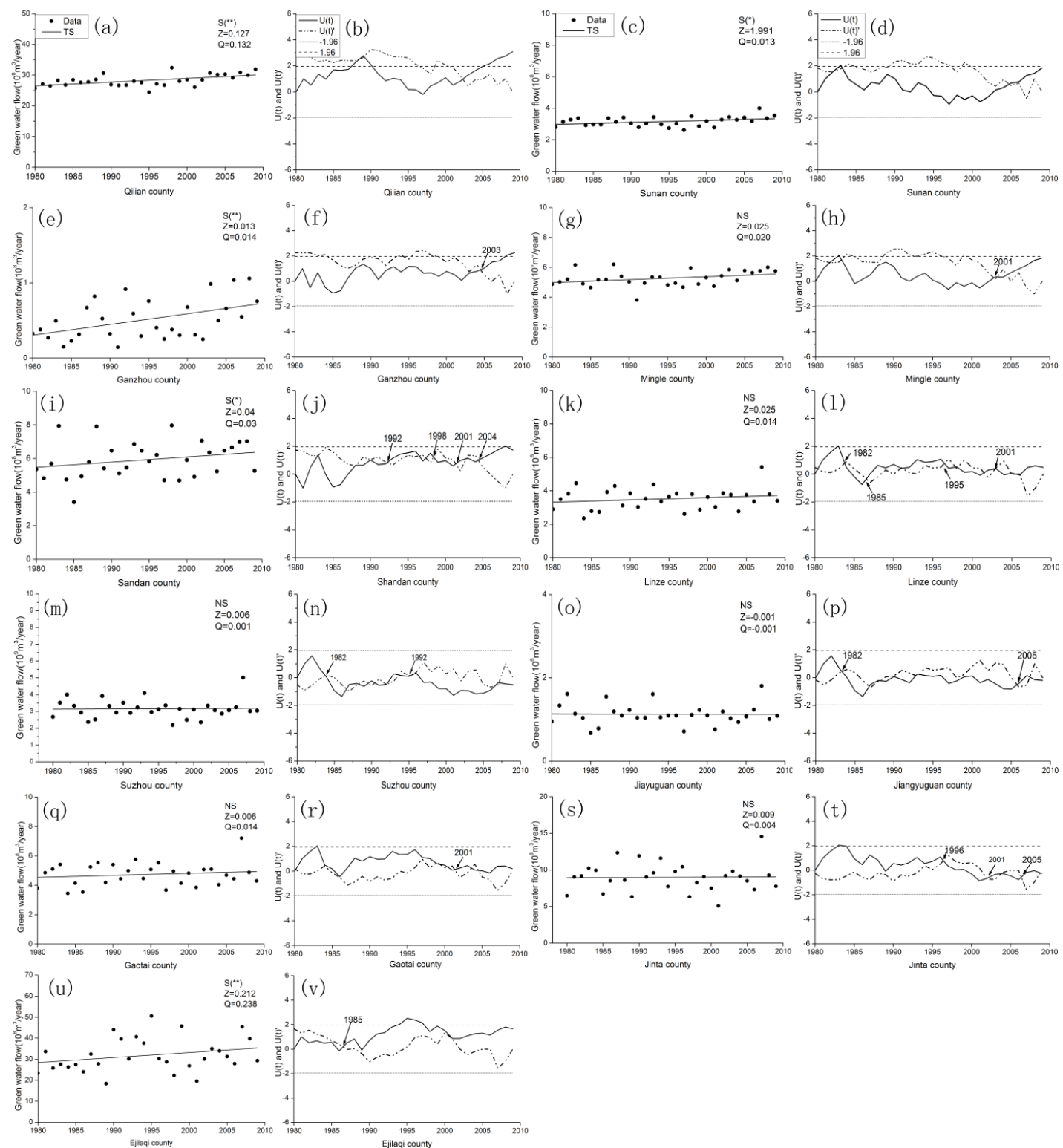

Figure 5: Dynamics of green water flow for eleven counties of the Heihe River basin, including Qilian (a and b), Sunan (c and d),

Ganzhou (e and f), Mingle (g and h), Shandan (i and j), Linze (k and l), Suzhou (m and n), Jiay uguan (o and p), Gaotai (q and r), Jinta (s and t) and Ejilaqi ( $\mathrm{u}$ and v). Note: TS stands for the Theil-Sen test; **indicates the significant level is at $\mathrm{p}<0.01$; $*$ indicates the 
Hydrol. Earth Syst. Sci. Discuss., doi:10.5194/hess-2016-241, 2016

Manuscript under review for journal Hydrol. Earth Syst. Sci.

Published: 13 June 2016
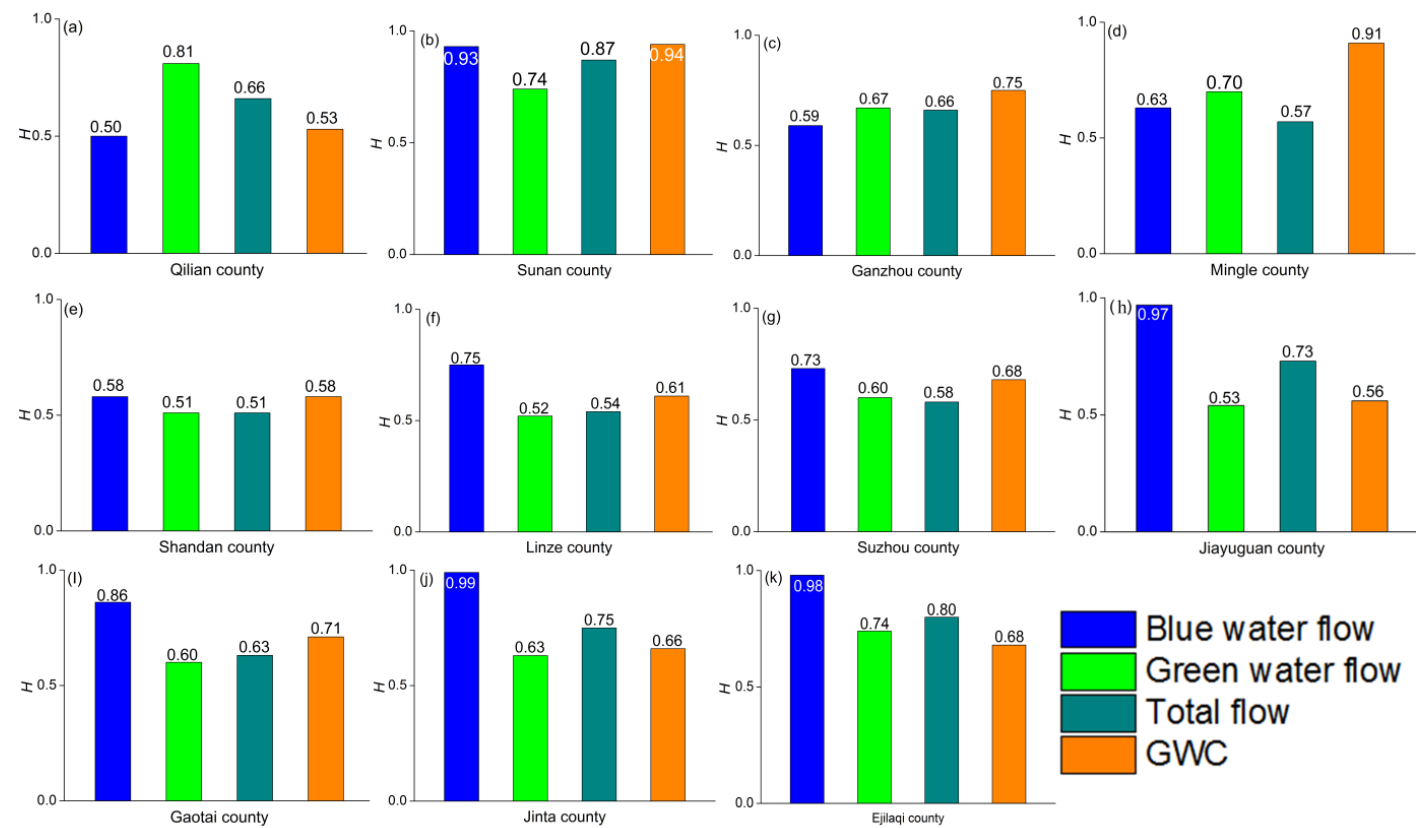

Blue water flow

Green water flow

Total flow

GWC

Figure 6: The Hurst index $(\mathrm{H})$ for trends in three flows (blue water, green water and total flows) and the GWC (the proportion of the total flows accounted for by the green water flow) for eleven counties of the Heihe River basin. Values of $\mathrm{H}>0.5$ indicate the trend from 1980 to 2009 will continue in the future; while $\mathrm{H}<0.5$ indicate the trend will change direction.

Table 1. SWAT model performance during the calibration and validation period

\begin{tabular}{|c|c|c|c|c|c|c|}
\hline \multirow[t]{2}{*}{ Station } & \multicolumn{3}{|c|}{ Calibration } & \multicolumn{3}{|c|}{ Validation } \\
\hline & $N S$ & $R^{2}$ & $R S R$ & $N S$ & $R^{2}$ & $R S R$ \\
\hline Zamashene & 0.76 & 0.92 & 0.08 & 0.74 & 0.90 & 0.09 \\
\hline Yingluoxia & 0.71 & 0.85 & 0.10 & 0.73 & 0.80 & 0.12 \\
\hline Zhenyixia & 0.68 & 0.61 & 0.13 & 0.63 & 0.55 & 0.16 \\
\hline Langxinshan & 0.52 & 0.62 & 0.19 & 0.56 & 0.57 & 0.18 \\
\hline Dongjuy anhai & 0.52 & 0.53 & 0.17 & 0.51 & 0.52 & 0.22 \\
\hline
\end{tabular}

Table 2. Comparison between the simulated and observed annual green water flow in 2007 (Units: $\mathrm{mm} \mathrm{a}^{-1}$ )

\begin{tabular}{lccc}
\hline Stations & Observed ET & Simulated ET & Relative error \\
\hline Jinta & 114 & 110 & $3.51 \%$ \\
Gaotai & 101 & 97 & $3.96 \%$ \\
Zhangye & 188 & 181 & $3.72 \%$ \\
\hline
\end{tabular}


Hydrol. Earth Syst. Sci. Discuss., doi:10.5194/hess-2016-241, 2016

Manuscript under review for journal Hydrol. Earth Syst. Sci.

Published: 13 June 2016

\begin{tabular}{lccc}
\hline Linze & 173 & 183 & $5.78 \%$ \\
Shandan & 136 & 141 & $3.68 \%$ \\
\hline
\end{tabular}

Table 3. The results of the Mann-Kendall test (MK), sequential Mann-Kendall test (SMK), and Theil-Sen estimator test (TS) for eleven counties of GWC in the Heihe River basin.

\begin{tabular}{|c|c|c|c|c|c|c|c|}
\hline Counties & MK & SMK & TS & & MK & SMK & TS \\
\hline Qilian & $\mathrm{NS} \downarrow$ & $1984 \uparrow 2009 \downarrow$ & -0.010 & Jinta & $\mathrm{NS} \uparrow$ & $1985 \downarrow 2003 \uparrow$ & 0.100 \\
\hline Suzhou & $\mathrm{NS} \downarrow$ & $1984 \downarrow 2006 \downarrow$ & -0.020 & Jiay uguan & $\mathrm{NS} \uparrow$ & $1983 \downarrow 2006 \uparrow$ & 0.010 \\
\hline Shandan & $\mathrm{NS} \downarrow$ & $2001 \downarrow$ & -0.050 & Gaotai & $\mathrm{NS} \downarrow$ & $1982 \downarrow$ & -0.200 \\
\hline Mingle & $\mathrm{NS} \uparrow$ & $2006 \uparrow$ & 0.037 & Ganzhou & $\mathrm{NS} \uparrow$ & $2004 \uparrow$ & 0.180 \\
\hline Linze & $\mathrm{NS} \downarrow$ & $2006 \downarrow$ & -0.09 & Ejilaqi & $\mathrm{NS} \uparrow$ & $1996 \downarrow 2004 \uparrow$ & 0.170 \\
\hline Sunan & $\mathrm{S}(*) \uparrow$ & $1984 \uparrow 2009 \downarrow$ & 0.024 & & & & \\
\hline
\end{tabular}

Note: TS stands for the Theil-Sen test and the value of presents the change rate; $\uparrow$ indicates an increasing trend, whereas $\downarrow$ indicates a

5 decreasing trend; * indicates the significant level at $\mathrm{p}<0.05$; NS represents the test is not significant.

Table 4. Dynamics of total water flow in the eleven counties in Heihe River basin.

\begin{tabular}{|c|c|c|c|c|c|c|c|}
\hline Counties & MK & SMK & TS & Counties & MK & SMK & TS \\
\hline Suzhou & $\mathrm{NS} \uparrow$ & $1998 \uparrow$ & 0.037 & Jinta & $\mathrm{NS} \downarrow$ & $2004 \downarrow$ & -0.034 \\
\hline Shandan & $\mathrm{NS} \uparrow$ & $2001 \uparrow$ & 0.048 & Jiay uguan & $\mathrm{NS} \downarrow$ & $2000 \downarrow$ & -0.004 \\
\hline Qilian & $\mathrm{NS} \uparrow$ & $2007 \uparrow$ & 0.175 & Gaota & $\mathrm{S}\left({ }^{*}\right) \uparrow$ & $1986 \uparrow$ & 0.0700 \\
\hline Mingle & $\mathrm{S}\left({ }^{*}\right)$ & $2004 \uparrow$ & 0.031 & Ganzhou & $\mathrm{S}\left({ }^{*}\right) \uparrow$ & $2003 \uparrow$ & 0.020 \\
\hline Linze & $\mathrm{NS} \uparrow$ & $2004 \uparrow$ & 0.027 & Ejilaqi & $\mathrm{S}\left({ }^{*}\right) \uparrow$ & $1984 \uparrow$ & 0.250 \\
\hline Sunan & $\mathrm{NS} \uparrow$ & $1984 \downarrow 2006 \uparrow$ & 0.020 & & & & \\
\hline
\end{tabular}

Note: MK represents Mann-Kendall test; SMK represents sequential Mann-Kendall test; TS stands for the Theil-Sen test and its values represent the change rate; $\uparrow$ declares an increase trend and $\downarrow$ declare an decrease trend; *signals a significance at $p<0$. 05; NS represents the test is not significant.

Table 5. Coefficients of determination (DC) of mean temperature for three flows and GWC (proportion of green water flow in total flows) in eleven counties of Heihe River basin during 1980-2009.

\begin{tabular}{lllllllllllll}
\hline Variables & Qilian & Suzhou & Shandan & Mingle & Linze & Jinta & Jiayuguan & Gaotai & Ganzhou Ejilaqi & Sunan \\
\hline Blue water flow & 0.01 & 0.15 & 0.01 & 0.03 & 0.05 & 0.06 & 0.02 & 0.15 & 0.03 & 0.03 & 0.01 \\
\hline
\end{tabular}


Hydrol. Earth Syst. Sci. Discuss., doi:10.5194/hess-2016-241, 2016

Manuscript under review for journal Hydrol. Earth Syst. Sci.

Published: 13 June 2016

(c) Author(s) 2016. CC-BY 3.0 License.

\begin{tabular}{lcccccccccccc}
\hline Green water flow & 0.31 & 0.04 & 0.02 & 0.02 & 0.01 & 0.02 & 0.04 & 0.03 & 0.06 & 0.02 & 0.11 \\
Total water flow & 0.09 & 0.08 & 0.02 & 0.04 & 0.01 & 0.01 & 0.03 & 0.07 & 0.06 & 0.02 & 0.03 \\
GWC & 0.01 & 0.01 & 0.02 & 0.03 & 0.03 & 0.03 & 0.03 & 0.02 & 0.03 & 0.03 & 0.04 \\
\hline
\end{tabular}

Table 6. Coefficients of determination (DC) of rainfall for blue water flow, green water flow, total water flow in eleven counties in the Heihe River basin in the past three decades.

\begin{tabular}{lcccccccccccccccccc}
\hline Variables & Qilian & Suzhou & Shandan & Mingle & Linze & Jinta & Jiayuguan & Gaotai & Ganzhou & Ejilaqi & Sunan \\
\hline Blue water flow & 0.90 & 0.03 & 0.81 & 0.32 & 0.068 & 0.03 & 0.03 & 0.038 & 0.21 & 0.02 & 0.70 \\
Green water flow & 0.56 & 0.88 & 0.84 & 0.85 & 0.96 & 0.90 & 0.86 & 0.94 & 0.25 & 0.97 & 0.80 \\
Total water flow & 0.90 & 0.31 & 0.88 & 0.81 & 0.90 & 0.78 & 0.6 & 0.62 & 0.32 & 0.91 & 0.85 \\
GWC & 0.77 & 0.81 & 0.60 & 0.22 & 0.44 & 0.79 & 0.82 & 0.28 & 0.03 & 0.90 & 0.39 \\
\hline
\end{tabular}

